\title{
Physicochemical characteristic, nutrient, and fish production in different types of mangrove forest in North Sumatra and Aceh Provinces of Indonesia
}

\author{
Mohammad Basyuni ${ }^{1,2 *}$, Bejo Slamet ${ }^{1,2}$, Nurdin Sulistiyono ${ }^{1,2}$, Erman Munir $^{2,3}$, \\ Alejandra G Vovides ${ }^{4}$, Pete Bunting ${ }^{5}$ \\ ${ }^{1}$ Dept. of Forestry, Faculty of Forestry, Universitas Sumatera Utara, Medan, Indonesia \\ ${ }^{2}$ Ctr. of Excellence for Mangrove, Universitas Sumatera Utara, Medan, Indonesia \\ ${ }^{3}$ Dept. of Biology, Faculty of Mathematics and Natural Sciences, Universitas Sumatera \\ Utara, Medan, Indonesia \\ ${ }^{4}$ Sch. of Geographical and Earth Sciences, University of Glasgow, East Quadrangle, \\ Glasgow, United Kingdom \\ ${ }_{5}^{5}$ Dept. of Geography and Earth Sciences, Aberystwyth University, Aberystwyth, Ceredigion, \\ United Kingdom \\ *Corresponding Author:m.basyuni@usu.ac.id
}

\begin{abstract}
Mangrove forests are highly productive ecosystems that sustain marine life, including fish communities. This study aimed to analyse mangrove characteristics, physicochemical parameters, nutrient and primary production derived from mangrove litter and estimate the fish production. The study was conducted at five mangrove sites in North Sumatra and the Aceh Provinces, Indonesia. Two sites represented natural forest at North Sumatra and Aceh (Jaring Halus and Langsa). In comparison, two sites were mangroves converted into oil palm plantations (Pulau Sembilan and Pulau Kampai, North Sumatra). The fifth site was a mangrove forest converted into aquacultural ponds (Percut Sei Tuan, North Sumatra). The study displays the dissemination of mangrove species in five different mangrove sites showing diversity. Avicennia spp found in estuarine near a coastal area, Rhizophora spp spread across the sites, and Sonneratia spp were more likely to occur in the mouth of the upstream river. Litter production at the present study site was dominated by Rhizophora spp., followed by Avicennia spp. This finding was very closely related to the nutrients resulting from litter decomposition in the mangrove ecosystem. The primary production value of $870-1,747 \mathrm{~g} \mathrm{C} \mathrm{m}^{-2}$ year had a significant role as the beginning of the estuary food chain. Our results show a close association between fish productivity and mangrove management, and conservation status. The highest fish production was found in the well-preserved forests (Jaring Halus and Langsa), followed by the sites converted to palm oil plantations (Pulau Sembilan and Pulau Kampai). At the same time, the least fishing productivity was identified at the fishing ponds (Percut Sei Tuan). The present study provides further evidence of the significant role of mangrove ecosystems for fisheries and calls for effective restoration programs to support local food security along the coast of Indonesia.
\end{abstract}

Keywords: Fish production; leaf litter; mangrove restoration; nutrient; primary production.

\section{Introduction}

The conservation of mangrove ecosystems has been closely associated with their productivity and human social wellbeing (Zaldívar-Jiménez et al., 2010; Barbier et al., 2011; Sheaves et al., 2017).
Mangrove forests produce nutrients that nourish marine waters, playing an important role in nutrient cycling (Thatoi et al., 2013) and sustaining highly commercially important species in local and wider market fisheries 
(i.e., fish, shrimp, crabs and bivalves), providing a relevant source of livelihoods, especially along the coast and river estuaries. However, mangroves remain one of the most threatened ecosystems worldwide by land-use change and the aquaculture farming industry (Valiela et al., 2001; Aburto-Oropeza et al., 2008; Barbier et al. 2011). This has urged restoration efforts worldwide (Ellison, 2000) and called for a more comprehensive understanding of environmental drivers of productivity, as well as for the identification of environmental indicators that can inform on the success of restoration activities and management policies (Ellison, 2000; Barbier et al., 2011; Vovides et al., 2011a).

A relevant indicator of restoration success could be provided by linking vegetation structure and litter production with fish biomass. Litter production is a major source of organic matter in estuarine sediments (Davis et al., 2003), and litter decomposition processes provide (1) detritus for microfauna and (2) essential nutrient elements for plant growth (Crawshaw et al., 2019). Hence litter production, along with stand and faunal biomass calculations, can provide valuable information on mangrove productivity, decomposition rates, and nutrient cycling (Hutchison et al., 2014a). For instance, the nutrient composition of the litter can indicate the efficiency of the nutrients used and which nutrients are limiting within the system, providing key elements of productivity (Ananda et al., 2007).

While vegetation provides refugee for fish and detritus supports the food chain, fishing productivity can be closely linked to vegetation structure and litter dynamics (Nagelkerken et al., 2008, Hutchison et al., 2014b). From the moment of litter production, detritivores and bacteria actively participate in leaf decay, recycling nutrients (i.e., Carbon, Nitrogen, and Phosphorus). The faster the litter decay occurs, the more likely it is that nutrients will be maintained within the ecosystem
(Li \& Ye, 2014) and create a positive productivity loop. A more abundant and diverse community of detritivores will contribute to faster litter decay, higher nutrient availability, and productivity (Middleton \& McKee, 2001). However, if decay rates are slow, the probability of nutrient export through the eater column is higher (Nagelkerken et al., 2008). Primary productivity can ultimately determine fish stock within mangroves (Friedland et al., 2012; Hutchison et al., 2014a). Although litter decay and nutrient cycling have been well studied in the context of nutrient availability and ecosystem productivity (Middleton \& McKee, 2001; Davis et al., 2003; Ananda et al., 2007; Nagelkerken et al., 2008; Contreras et al., 2017), and from a restoration context (Nagelkerken et al., 2008; Vovides et al., 2011a; Marquez et al., 2017), and that mangrove vegetation has been positively associated with fishing productivity (Aburto-Oropeza et al., 2008, Fitri et al., 2018), relevant information quantifying fish biomass with litter production and associated nutrient release rates remains limited. Furthermore, studies comparing management conditions (or status of restoration), notably from Indonesian mangroves, are currently unavailable, despite the important role of mangroves to support sustainable fisheries and aquatic organisms. This study aimed to assess the changes in fish productivity in response to mangrove forest structure and litter decay under different management scenarios:

1. Well conserved mangroves without significant disturbance.

2. Mangrove restoration from fishing ponds, and

3. Mangroves restored from the previous conversion to palm oil plantations. We estimated the primary productivity of phytoplankton from nutrients released by mangrove litter and related it to fish production within these management conditions. 


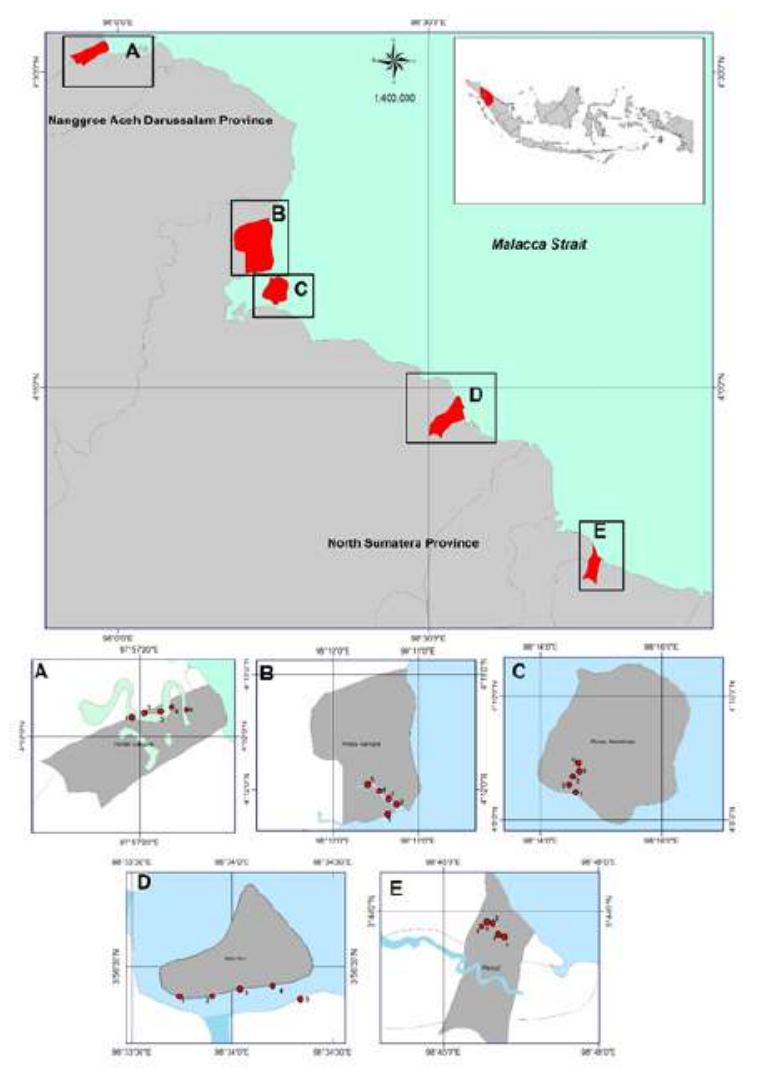

Fig. 1. Study area at five locations spread in North Sumatra and Aceh Province, A: Langsa, B: Pulau Kampai, C: Pulau Sembilan, D: Jaring Halus, dan E: Percut Sei Tuan.

\section{Materials and Methods}

\subsection{Study area}

This study was conducted within five mangrove forests of North Sumatra and Aceh Provinces, Indonesia (Table 1 and Figure 1). The sites were selected with their management condition; natural mangroves (Langsa and Jaring Halus), mangroves converted into the aquacultural ponds (Percut Sei Tuan), and mangroves shifted into oil palm plantation (Pulau Kampai and Pulau Sembilan).

\subsection{Forest structure}

Mangrove forest structure was assessed by establishing five sampling stations to monitor mangroves adjacent to the sea (stations 1 and 2, Table 1) and upstream mangroves (stations $3-5$, Table 1). Three $10 \times 10 \mathrm{~m}$ quadrats were delimited within each station, and the following parameters accounted for: tree species, number of trees, stem diameter, height
(Fitri et al., 2018). The collected data were used to estimate: Stand density (tree ha ${ }^{-1}$ ) for stands and each species, importance value index (IVI), and the Shannon-Wiener diversity index $\left(\mathrm{H}^{\prime}\right)$ was calculated as previously reported (Fitri et al., 2018).

\subsection{Measurement of physical and chemical} parameters

At each sampling plot, three samples of sediment were collected at random points to assess substrate type. Three samples were collected from surface and sub-surface water to measure temperature, salinity, dissolved oxygen (DO), $\mathrm{pH}$, current velocity, and humidity as previously described (Fitri et al., 2018; Al-Enezi et al., 2019). DO was measured using a DO meter (LutronDO-5510), $\mathrm{pH}$ was measured using a $\mathrm{pH}$ meter (EcoTestr $\mathrm{pH} 2$ ), the humidity was measured using a humidity meter (HTC-2), salinity was measured using a hand-refractometer (Atogo Master S28 $\mathrm{M})$, and current velocity was measured manually using a stopwatch. 
Table 1. Description of sample locations in North Sumatra and Aceh provinces

\begin{tabular}{|lll|}
\hline Location & East longitudes $\left(^{\circ}\right)$ & North latitudes $\left(^{\circ}\right)$ \\
Langsa 1 & $4^{\circ} 32^{\prime} 47.51^{\prime \prime}$ & $97^{\circ} 58^{\prime} 29.56^{\prime \prime}$ \\
Langsa 2 & $4^{\circ} 32^{\prime} 46.79^{\prime \prime}$ & $97^{\circ} 58^{\prime} 8.38^{\prime \prime}$ \\
Langsa 3 & $4^{\circ} 32^{\prime} 46.48^{\prime \prime}$ & $97^{\circ} 57^{\circ} 44.97^{\prime \prime}$ \\
Langsa 4 & $4^{\circ} 32^{\prime} 45.04^{\prime \prime}$ & $97^{\circ} 57^{\prime} 20.37$ \\
Langsa 5 & $4^{\circ} 32^{\prime} 44.67^{\prime \prime}$ & $97^{\circ} 57^{\prime} 9.44^{\prime \prime}$ \\
Pulau Kampai 1 & $4^{\circ} 8^{\prime} 35.55^{\prime \prime}$ & $98^{\circ} 14^{\prime} 28.56^{\prime \prime}$ \\
Pulau Kampai 2 & $4^{\circ} 8^{\prime} 37.20^{\prime \prime}$ & $98^{\circ} 14^{\prime} 22.83^{\prime \prime}$ \\
Pulau Kampai 3 & $4^{\circ} 8^{\prime} 41.64^{\prime \prime}$ & $98^{\circ} 14^{\prime} 25.08^{\prime \prime}$ \\
Pulau Kampai 4 & $4^{\circ} 8^{\prime} 45.80^{\prime \prime}$ & $98^{\circ} 14^{\prime} 28.69^{\prime \prime}$ \\
Pulau Kampai 5 & $4^{\circ} 8^{\prime} 51.40^{\prime \prime}$ & $98^{\circ} 14^{\prime} 27.15^{\prime \prime}$ \\
Pulau Sembilan 1 & $4^{\circ} 11^{\prime} 34.09^{\prime \prime}$ & $98^{\circ} 14^{\prime} 54.09^{\prime \prime}$ \\
Pulau Sembilan 2 & $4^{\circ} 11^{\prime} 48.32^{\prime \prime}$ & $98^{\circ} 15^{\prime} 0.08^{\prime \prime}$ \\
Pulau Sembilan 3 & $4^{\circ} 11^{\prime} 50.70^{\prime \prime}$ & $98^{\circ} 14^{\prime} 51.06^{\prime \prime}$ \\
Pulau Sembilan 4 & $4^{\circ} 11^{\prime} 57.70^{\prime \prime}$ & $98^{\circ} 14^{\prime} 38.08^{\prime \prime}$ \\
Pulau Sembilan 5 & $4^{\circ} 12.5^{\prime} 44^{\prime \prime}$ & $98^{\circ} 14^{\prime} 28.18$ \\
Jaring Halus 1 & $3^{\circ} 56^{\prime} 22.67^{\prime \prime}$ & $98^{\circ} 33^{\prime} 43.89^{\prime \prime}$ \\
Jaring Halus 2 & $3^{\circ} 56^{\prime} 22.62^{\prime \prime}$ & $98^{\circ} 33^{\prime} 51.92^{\prime \prime}$ \\
Jaring Halus 3 & $3^{\circ} 56^{\prime} 21.98^{\prime \prime}$ & $98^{\circ} 34^{\prime} 0.58^{\prime \prime}$ \\
Jaring Halus 4 & $3^{\circ} 56^{\prime} 22.12^{\prime \prime}$ & $98^{\circ} 34^{\prime} 9.97^{\prime \prime}$ \\
Jaring Halus 5 & $3^{\circ} 56^{\prime} 20.36^{\prime \prime}$ & $98^{\circ} 34^{\prime} 15.06^{\prime \prime}$ \\
Percut Sei Tuan 1 & $3^{\circ} 45^{\prime} 22.59^{\prime \prime}$ & $98^{\circ} 44^{\prime} 5.18^{\prime \prime}$ \\
Percut Sei Tuan 2 & $3^{\circ} 45^{\prime} 35.32$ & $98^{\circ} 44^{\prime} 3.06^{\prime \prime}$ \\
Percut Sei Tuan 3 & $3^{\circ} 45^{\prime} 44.51^{\prime \prime}$ & $98^{\circ} 43^{\prime} 48.65^{\prime \prime}$ \\
Percut Sei Tuan 4 & $3^{\circ} 45^{\prime} 38.05^{\prime \prime}$ & $98^{\circ} 43^{\prime} 39.96^{\prime \prime}$ \\
Percut Sei Tuan 5 & $3^{\circ} 45^{\prime} 29.36^{\prime \prime}$ & $98^{\circ} 43^{\prime} 37.45$ \\
\hline
\end{tabular}

Location numbering is also described as a station

\subsection{Mangrove litter production}

Production of mangrove litter was estimated by placing five $1 \times 1 \mathrm{~m}^{2}$ litter traps made of fishing nets mounted on squared frames and placed under tree canopies (Liu et al., 2017; Fitri et al., 2018) at an altitude of 1-1.5 m above ground level in each plot. Trapped litter was collected every 14 days for a total period of two months. The collected samples of litter were then separated by component (leaves, twigs, and fruits), weighted before (fresh weight) oven drying at $105^{\circ} \mathrm{C}$ until a constant weight measurement was achieved, and dry weight was recorded.
2..5. Relation between forest structure and physicochemical parameters

The relationship between mangrove characteristics and environmental parameters was analyzed using agglomerative hierarchical clustering (AHC) to be grouped in classes with similar or adjacent characteristics (Dasgupta \& Long 2005; Fitri et al., 2018). Thus, analysis helps classify research stations by similarity of attributes and aided in recognizing mangrove classes as a function of their litter. 
2.6 Fish productivity in response to primary productivity

Fish productivity was estimated by computing potential nutrient release into the water, which would then be available to phytoplankton for photosynthesis as primary production (Fitri et al., 2018). The total potential nutrient release was calculated as:

$\Sigma$ Nutrient $\left(\mathrm{g} \mathrm{m}^{-2}\right)=\Sigma(\operatorname{LLx} \times \mathrm{RNx})+(\mathrm{LLx} \times$ $\mathrm{RPx})$

where LL is the litter production, $\mathrm{RNx}$ denotes $\mathrm{N}$ release $(\mathrm{RN})$ potential for species $\mathrm{x}$, and $\mathrm{RPx}$ is the potential release of phosphorus (RP) for species $\mathrm{X}$.

A C: $\mathrm{N}$ ratio (carbon: nitrogen), the ratio for protein production, was taken as 17:1 (GilWeir et al., 2011). The amount of nitrogen that changes to dry weight ( $\mathrm{g} \mathrm{C}$ ) is $1 \mathrm{~g} \mathrm{C}=2 \mathrm{~g}$ of dry biomass weight (Gil-Weir et al., 2011). Phytoplankton (g) C: Nutrient $(\mathrm{g}) \mathrm{N}$ ratio $=17$ : 1.

Primary productivity (PP) was then estimated is determined through the litter nutrient release estimations (Eq. 1, Fitri et al., 2018) as:

$\Sigma \mathrm{PP}=\Sigma$ Nutrient $\times 2 \times 17$.

Finally, herbivore fish production (g wet weight of fish $\mathrm{m}^{-2}$ ) was calculated from Eq. 2 by computing the primary productivity conversion efficiency Beveridge, 1984, as follows:

fish $(\mathrm{HF})=10 \times(\mathrm{b} \times \Sigma \mathrm{PP})$

where HF is the production of herbivore fish, $b$ is the percentage value of conversion into grams of fish carbon per square meter per day ( $\mathrm{g} \mathrm{C}^{-}$fish $\mathrm{m}^{-2}$ ). While carbon content in fish is $10 \%$ of the weight of the fish, or on the other hand, the wet weight of the fish is equal to 10 times the carbon content of the fish.

Production of carnivore fish $(\mathrm{CF})$ was further estimated assuming a $10 \%$ efficiency in the energy flow; $\mathrm{CF}$ was derived from $10 \%$ of $\mathrm{HF}$ (Fitri et al., 2018).
Total fish production was calculated as

$$
\Sigma \mathrm{FB}=\mathrm{HF}+\mathrm{CF} .
$$

\subsection{Statistical analysis}

Data were analyzed by one-way analysis of variance (ANOVA) followed by Duncan's multiple range test for location comparisons. The value of $\mathrm{P}<0.05$ was selected as a limit of statistical significance. All statistical analyses were constructed using the IBM SPSP Statistics ver. 22 (IBM Cooperation, Armonk, NY).

\section{Results and Discussion}

\subsection{Mangrove forest structure}

Table 2 summarizes mangrove species found in the study sites. The highest species-specific mangrove density was seen for A. marina with a density between 2-24 trees $\mathrm{m}^{-2}$, while the lowest (between 1-28 trees $\mathrm{m}^{-2}$ ) was observed for Sonneratia spp. which was not found in the Langsa and Percut sites. The present study displays the dissemination of mangrove species in five different mangrove sites showing different densities and diversity.

Avicennia spp. is mainly found inside the estuaries, near the coastal area. This is consistent with its pioneer nature on sheltered coastal lands, where they can colonize salty mudflats (Borkar et al., 2011; Fitri et al., 2018). It is interesting to note that Rhizophora spp. was evenly represented across all sites, especially R. apiculata. This condition may be due to the high adaptation to the surrounding environment (Dangremond et al., 2015; Phuphumirat et al., 2016). Also, Rhizophora spp. has a shorter and slender hypocotyl than other species that allow it to be carried by seawater and disperse further distances (Phuphumirat et al., 2016). The existence of Sonneratia spp. found in almost all stations indicated that this species could grow on the part that gets freshwater input, primarily on the species of S. caseolaris (Aznan et al., 2018). Furthermore, in the species of S. alba, 
Table 2. Mangrove species found in the study sites.

\begin{tabular}{|c|c|c|c|c|c|c|}
\hline Location & Species & Station 1 & Station 2 & Station 3 & Station 4 & Station 5 \\
\hline \multirow[t]{4}{*}{ Langsa } & A. marina & 0 & 2 & 10 & 12 & 22 \\
\hline & R. apiculata & 10 & 14 & 4 & 2 & 2 \\
\hline & R. stylosa & 8 & 6 & 2 & 0 & 0 \\
\hline & A. alba & 0 & 0 & 0 & 14 & 4 \\
\hline Jarin & R. apiculata & 8 & 16 & 4 & 16 & 4 \\
\hline \multirow[t]{4}{*}{ Halius } & R. stylosa & 4 & 0 & 0 & 16 & 0 \\
\hline & R. mucronata & 8 & 4 & 0 & 0 & 0 \\
\hline & A. marina & 4 & 12 & 15 & 24 & 8 \\
\hline & S. alba & 0 & 0 & 0 & 0 & 28 \\
\hline Pulau & R. apiculata & 9 & 3 & 8 & 5 & 7 \\
\hline \multirow[t]{3}{*}{ Kampai } & R. stylosa & 0 & 4 & 0 & 2 & 1 \\
\hline & A. marina & 8 & 5 & 7 & 0 & 0 \\
\hline & S. alba & 1 & 4 & 1 & 0 & 0 \\
\hline Pula & R. apiculata & 4 & 5 & 7 & 3 & 9 \\
\hline \multirow[t]{5}{*}{ Sembilan } & R. stylosa & 3 & 2 & 5 & 4 & 7 \\
\hline & A.alba & 4 & 0 & 0 & 2 & 1 \\
\hline & A. marina & 6 & 8 & 5 & 5 & 3 \\
\hline & S. alba & 1 & 2 & 0 & 4 & 6 \\
\hline & S. caseolaris & 3 & 0 & 1 & 1 & 0 \\
\hline \multirow[t]{5}{*}{ Percut } & R. apiculata & 1 & 0 & 0 & 0 & 2 \\
\hline & R. mucronata & 2 & 1 & 0 & 0 & 0 \\
\hline & A. marina & 5 & 3 & 3 & 7 & 1 \\
\hline & A. alba & 3 & 2 & 4 & 2 & 1 \\
\hline & R. stylosa & 0 & 0 & 1 & 2 & 0 \\
\hline
\end{tabular}

Table 3. Physical and chemical parameters in the location sites.

\begin{tabular}{|c|c|c|c|c|c|c|}
\hline Parameter & Unit & Langsa & $\begin{array}{l}\text { Jaring } \\
\text { Halus }\end{array}$ & $\begin{array}{l}\text { Pulau } \\
\text { Kampai }\end{array}$ & $\begin{array}{c}\text { Pulau } \\
\text { Sembilan }\end{array}$ & Percut \\
\hline $\begin{array}{l}\text { Air } \\
\text { temperature (At) }\end{array}$ & ${ }^{\circ} \mathrm{C}$ & $39.00 \pm 3.1 \mathrm{a}$ & $33.90 \pm 2.6 b c$ & $33.98 \pm 4.2 b c$ & $35.75 \pm 5.8 b$ & $32.11 \pm 1.4 \mathrm{c}$ \\
\hline $\begin{array}{l}\text { Seawater } \\
\text { temperature (Swt) }\end{array}$ & ${ }^{\circ} \mathrm{C}$ & $31.88 \pm 1.5 \mathrm{a}$ & $29.26 \pm 1.3 \mathrm{c}$ & $30.03 \pm 1.1 \mathrm{~b}$ & $30.08 \pm 1.7 \mathrm{~b}$ & $28.09 \pm 1.2 \mathrm{c}$ \\
\hline Salinity (S) & $\%$ & $36.90 \pm 1.3 \mathrm{a}$ & $18.40 \pm 2.5 \mathrm{~d}$ & $34.55 \pm 1.4 \mathrm{~b}$ & $34.30 \pm 1.0 \mathrm{~b}$ & $24.80 \pm 2.8 \mathrm{c}$ \\
\hline DO & $\mathrm{mg} / \mathrm{l}$ & $4.07 \pm 0.7 \mathrm{c}$ & $7.72 \pm 0.1 \mathrm{a}$ & $6.46 \pm 0.3 b$ & $6.54 \pm 0.4 b$ & $3.60 \pm 0.4 \mathrm{~d}$ \\
\hline $\mathrm{pH}$ & - & $6.73 \pm 0.4 \mathrm{a}$ & $6.80 \pm 0.6 \mathrm{a}$ & $6.80 \pm 0.6 \mathrm{a}$ & $6.04 \pm 0.8 b$ & $5.20 \pm 0.6 c$ \\
\hline $\begin{array}{l}\text { Current } \\
\text { velocity }(\mathrm{Cv})\end{array}$ & $\mathrm{m} / \mathrm{s}$ & $0.13 \pm 0.0 \mathrm{a}$ & $0.10 \pm 0.0 \mathrm{ab}$ & $0.08 \pm 0.0 \mathrm{~b}$ & $0.10 \pm 0.0 \mathrm{ab}$ & $0.08 \pm 0.0 \mathrm{~b}$ \\
\hline $\begin{array}{l}\text { Humidity }(\mathrm{H}) \\
\text { composition }\end{array}$ & $\%$ & $88.40 \pm 3.4 \mathrm{~b}$ & $87.20 \pm 1.9 b$ & $93.50 \pm 2.2 \mathrm{a}$ & $92.40 \pm 1.5 \mathrm{a}$ & $84.30 \pm 2.0 \mathrm{c}$ \\
\hline Sediment & $\%$ & & & & & \\
\hline Sand & & $58.00 \pm 7.7 \mathrm{a}$ & $41.20 \pm 3.5 b$ & $48.20 \pm 9.7 \mathrm{ab}$ & $62.33 \pm 9.0 \mathrm{a}$ & $50.60 \pm 7.7 \mathrm{ab}$ \\
\hline Silt & & $30.00 \pm 6.8 \mathrm{ab}$ & $37.20 \pm 4.5 \mathrm{a}$ & $31.60 \pm 7.3 \mathrm{ab}$ & $21.67 \pm 5.9 b$ & $33.60 \pm 3.8 \mathrm{ab}$ \\
\hline Clay & & $12.00 \pm 2.4 \mathrm{a}$ & $21.60 \pm 5.2 \mathrm{a}$ & $20.20 \pm 9.3 \mathrm{a}$ & $16.00 \pm 4.4 \mathrm{a}$ & $15.80 \pm 6.8 \mathrm{a}$ \\
\hline Sediment texture & & Sandy clay & Silty & Sandy silty & Sandy clay & Sandy silty \\
\hline C-organic & $\%$ & $7.93 \pm 1.4 \mathrm{ab}$ & $2.42 \pm 0.3 \mathrm{~d}$ & $5.51 \pm 2.2 \mathrm{bc}$ & $11.03 \pm 1.4 \mathrm{a}$ & $4.03 \pm 0.6 \mathrm{~cd}$ \\
\hline
\end{tabular}

Data are represented as mean $\pm \mathrm{SD}$. Means with the same superscript are not significantly different for each other $(\mathrm{P}<0.05)$ using Duncan's test. 
it is often found in more salty areas and gets more seawater intake (Whitfield, 2017; Fitri et al., 2018). During the field observed, Sonneratia spp. were detected more likely to grow in the mouth of the upstream river.

\subsection{Physical and chemical parameters}

Table 3 shows the physical and chemical parameters measured in the research areas of aquatic temperature ranged from 28.14 to $31.88^{\circ} \mathrm{C}$ with oxygen levels in all sites statistically were significantly different, ranging from 3.60 to $7.72 \mathrm{mg} / \mathrm{l}$. Furthermore, $\mathrm{pH}$ ranged from 5.20 to 6.80 .

The current speed is very slow to moderate, ranging from $0.07-0.12 \mathrm{~m} / \mathrm{s}$. The range of DO in this study was within the range of DO reported in intertidal water for other mangroves (Al-Bader et al., 2014). Other physicochemical parameters, salinity ranged between 18.40-36.90\%, and humidity ranged between 84.30-93.50\%. Sediment composition was dominated by sandy substrate ranged 41$62 \%$, with the highest in Pulau Sembilan and the lowest sandy was Jaring Halus. In the case of C-organic, the highest, as shown in Pulau Sembilan, and the lowest in Jaring Halus (Table 3). Salinity was significantly different among the sites.

It has been reported that the lower salinity of the upper river might be caused by more significant freshwater input compared to seawater (Chambers et al., 2013).

Therefore, Langsa, Pulau Kampai, and Pulau Sembilan have relatively high significant salinity and a significant decrease in salinity value upstream of Jaring Halus. Salinity levels ranging from 10-30 \%o are also appropriate salinity concentration in mangrove survival varies according to the species (Dangremond et al., 2015; Mendez-Alonzo et al., 2016; Kodikara et al., 2018). Mangrove species often depict growth stimulation at low salinity (25\% seawater $/ 5 \%$ salt concentration) and moderate salinity $(50 \%$ seawater/15 \%o salinity) and then a decline in growth with further increases in salinity (Basyuni et al. 2014, 2019; Mendez-Alonzo et al., 2016; Kodikara et al., 2018). This study suggested

Table 4. A location classified based on the agglomerative hierarchical clustering (AHC) analysis

\begin{tabular}{|c|c|c|c|c|c|c|c|c|c|c|}
\hline Group & At $\left({ }^{\circ} \mathrm{C}\right)$ & Swt $\left({ }^{\circ} \mathrm{C}\right)$ & S (\%o) & $\mathrm{DO}(\mathrm{mg} / \mathrm{l})$ & $\mathrm{pH}$ & $\mathrm{Vc}(\mathrm{m} / 2)$ & $\mathrm{H}(\%)$ & $\mathrm{Td} \mathrm{cm})$ & Th (m) & Ns \\
\hline 1 & $\begin{array}{c}37.38 \pm \\
4.5^{\mathrm{a}}\end{array}$ & $\begin{array}{c}30.98 \pm \\
1.6^{\mathrm{a}}\end{array}$ & $\begin{array}{c}35.60 \pm \\
1.2^{\mathrm{a}}\end{array}$ & $\begin{array}{l}5.23 \pm \\
0.6^{\mathrm{b}}\end{array}$ & $\begin{array}{l}6.38 \pm \\
0.6^{\mathrm{ab}}\end{array}$ & $\begin{array}{l}0.11 \pm \\
0.0^{\mathrm{a}}\end{array}$ & $\begin{array}{r}90.4 \pm \\
2.4^{\mathrm{ab}}\end{array}$ & $\begin{array}{c}16 \pm \\
4.0^{\mathrm{b}}\end{array}$ & $\begin{array}{l}4 \pm \\
0.6\end{array}$ & $\begin{array}{c}6 \pm \\
0.8^{\mathrm{a}}\end{array}$ \\
\hline 2 & $\begin{array}{c}33.90 \pm \\
2.6^{\mathrm{ab}}\end{array}$ & $\begin{array}{c}29.26 \pm \\
1.3^{\mathrm{a}}\end{array}$ & $\begin{array}{c}18.40 \pm \\
2.5^{\mathrm{c}}\end{array}$ & $\begin{array}{l}7.72 \pm \\
0.1^{\mathrm{a}}\end{array}$ & $\begin{array}{l}6.80 \pm \\
0.6^{\mathrm{a}}\end{array}$ & $\begin{array}{l}0.10 \pm \\
0.0^{\mathrm{a}}\end{array}$ & $\begin{array}{c}87.2^{ \pm} \\
1.9^{\mathrm{c}}\end{array}$ & $\begin{array}{l}27 \pm \\
3.0^{\mathrm{a}}\end{array}$ & $\begin{array}{l}8 \pm \\
1.2^{\mathrm{a}}\end{array}$ & $\begin{array}{l}5 \pm \\
0.2^{\mathrm{a}}\end{array}$ \\
\hline 3 & $\begin{array}{c}33.04 \pm \\
2.8^{\mathrm{b}}\end{array}$ & $\begin{array}{c}29.08 \pm \\
1.2^{\mathrm{a}}\end{array}$ & $\begin{array}{c}29.68 \pm \\
2.1^{b}\end{array}$ & $\begin{array}{l}5.03 \pm \\
0.4^{\mathrm{b}}\end{array}$ & $\begin{array}{l}6.00 \pm \\
0.6^{\mathrm{a}}\end{array}$ & $\begin{array}{l}0.08 \pm \\
0.0^{\mathrm{a}}\end{array}$ & $\begin{array}{r}88.9 \pm \\
2.1^{\mathrm{c}}\end{array}$ & $\begin{array}{l}13 \pm \\
2.0^{\mathrm{c}}\end{array}$ & $\begin{array}{l}4.8^{ \pm} \\
0.3^{\mathrm{c}}\end{array}$ & $\begin{array}{r}5 \pm \\
0.1^{\mathrm{a}}\end{array}$ \\
\hline
\end{tabular}

Data are represented as mean $\pm \mathrm{SD}$. At $=$ air temperature, $\mathrm{Swt}=$ sea water temperature, $\mathrm{S}=$ salinity, $\mathrm{Do}=$ dissolved oxygen $\mathrm{Vc}=$ velocity current, $\mathrm{H}=$ humidity, $\mathrm{Td}=$ tree diameter, $\mathrm{Th}=$ tree height, $\mathrm{Ns}=$ number of species. Means with the same superscript are not significantly different for each other $(\mathrm{P}<0.05)$ using Duncan's test. 


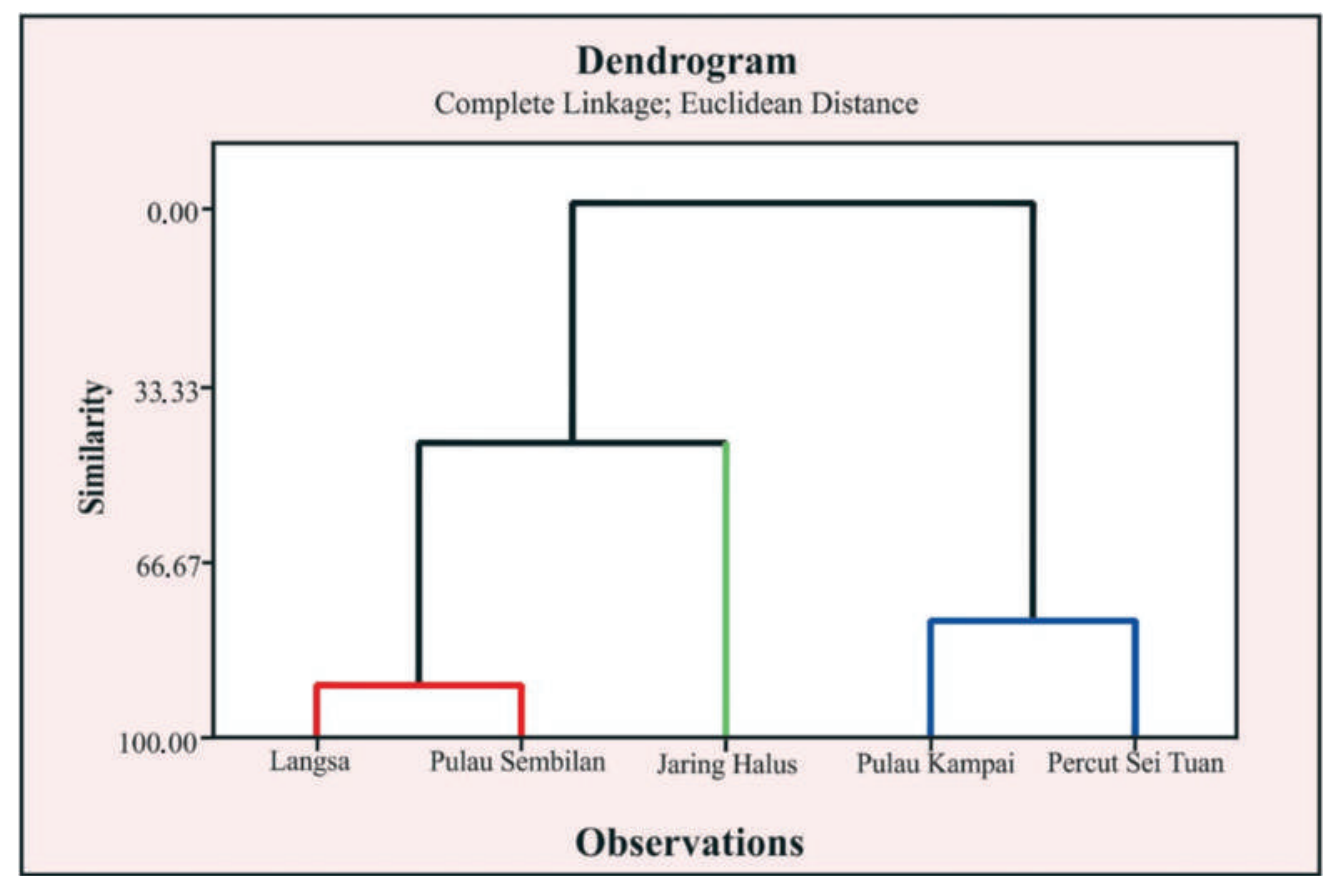

Fig. 2. Agglomerative hierarchical clustering (AHC) analysis. Mangrove sites were clustered by site attribute similarity, clustering Langsa, and Pulau Sembilan within group 1 (red lines), Jarin Halus (green line) more related to group 1 than to 3 (blue lines), which includes Mangroves at Pulau Kampai and Percut. The variables with more weight in the clustering were physicochemical parameters and stand density.

that several mangrove species tolerated to adapt either in saline or freshwater stress.

\subsection{Relation of mangrove characteristics and} physical and chemical parameters analysi

Based on agglomerative hierarchical clustering (AHC) analysis, mangrove individual observation locations are grouped into three groups based on existing physical and chemical parameters, as shown in Figure 2. The first group consists of locations in Langsa and Pulau Sembilan. This group was dominated by R. apiculata and A. marina with medium density, high salinity and humidity, and a sandy-clay substrate (Table 4).

The second group consisted of Jaring Halus only with mangrove R. apiculata, A. marina, and S. alba, which has very high density, the lowest salinity, and high mud. It has been demonstrated that there is a relationship between soil characteristics and mangrove species (Hossain \& Nuruddin, 2016).

Soils are made up of sand, silt, and clay in different combinations, and mud refers to a mixture of silt and clay, both of which are rich in organic matter (detritus) (Hossain \& Nuruddin, 2016), as represented in Jaring Halus. Group three consisted of locations in Pulau Kampai and Percut overgrown with vegetation type with low density and medium salinity. This grouping data is based on the object's concentration of the dendrogram (Figure. 2).

3.4 Importance value index and diversity index analysis

The calculation of the importance value index (IVI) showed that the highest value was in group 1 on Rhizophora spp. of $164.37 \%$ and the lowest in group 3 for Sonneratia spp. they were subjected to $29.02 \%$.

Based on the result of a Shannon-Weiner diversity index value ( $\left.\mathrm{H}^{\prime}\right)$, mangrove forests in group 1 had high diversity (3.02), followed by group 2 (2.97) and group 3 (1.73). In the present study, species diversity was higher than previous studies in Lubuk Kertang, North Sumatra, Indonesia. As for restored mangroves 
Table 5. Importance value index and diversity index of study sites

\begin{tabular}{|c|c|c|c|c|c|c|}
\hline Group & Species & $\begin{array}{c}\text { Relative } \\
\text { Density } \\
(\%)\end{array}$ & $\begin{array}{l}\text { Relative } \\
\text { Frequency } \\
\quad(\%)\end{array}$ & $\begin{array}{c}\text { Relative } \\
\text { Dominance } \\
(\%)\end{array}$ & IVI (\%) & $\mathrm{H}^{\prime}$ \\
\hline & Avicennia spp. & 22.82 & 35.90 & 14.38 & 73.09 & $3.02 \pm 0.1 \mathrm{a}$ \\
\hline \multirow[t]{3}{*}{1} & Rhizophora spp. & 65.10 & 46.15 & 53.12 & 164.37 & \\
\hline & Sonneratia spp. & 12.08 & 17.95 & 32.50 & 62.54 & \\
\hline & Avicennia spp. & 36.84 & 33.33 & 36.58 & 106.75 & $2.97 \pm 0.1 \mathrm{a}$ \\
\hline \multirow[t]{3}{*}{2} & Rhizophora spp. & 46.78 & 60.00 & 45.55 & 152.34 & \\
\hline & Sonneratia spp. & 16.38 & 6.67 & 17.87 & 40.91 & \\
\hline & Avicennia spp. & 48.57 & 46.67 & 46.57 & 141.81 & $1.73 \pm 0.1 b$ \\
\hline \multirow[t]{2}{*}{3} & Rhizophora spp. & 45.72 & 43.33 & 40.13 & 129.17 & \\
\hline & Sonneratia spp. & 5.71 & 10.00 & 13.30 & 29.02 & \\
\hline
\end{tabular}

Data of $\mathrm{H}^{\prime}$ are represented as mean $\pm \mathrm{SD}(\mathrm{n}=3)$. Means with the same superscript are not significantly different for each other $(\mathrm{P}<0.05)$ using Duncan's test.

$\left(\mathrm{H}^{\prime}=0.27-1.09\right.$, Fitri et al., 2018), mangrove species in Sungai Haji Dorani and Kuala Selangor with a Shannon-Weiner Index (H') value of 0.91 and 0.55 , respectively (Zhila et al., 2014), and compared to the natural mangrove forest in Palawan, Philippines $\left(\mathrm{H}^{\prime}=\right.$ 0.99) (Abino et al., 2014). This study indicated that natural mangrove forests in Langsa and Jaring Halus had considerable high species diversity (Table 5).

\subsection{Fish biomass and production estimation}

This finding was very closely related to the nutrients resulting from litter decomposition. The primary production value had a significant role as the beginning of the estuary food chain. In this circumstance, the highest fish productivity from Jaring Halus can be derived not only from its high productivity but can also be related to lower sediment salinity related to surrounding rivers and rainfall (Hutchison et al., 2014b, Méndez-Alonzo et al., 2016), and a potential higher litter decay rate, promoted by a well-established herbivore community, characteristic of mature preserved mangroves (Middleton \& McKey, 2001; Ananda et al., 2007, Whitfield, 2017). In contrast, degraded mangroves, often hyper-salinized due to vegetation cover loss and excess insolation (Vovides et al., 2011a; Vovides et al., 2011b), lose not only their detritivore community and thus their ability to contribute to the food chain. The lower fish productivity observed for the conserved site Langsa can be attributed to the relatively high salinity compared to Jaring Halus. Salinity reduces detrital decomposition (Contreras et al., 2017). However, its fish productivity was still $>50 \%$ higher than the restoring site within its group(Pulau Sembilan), suggesting litter decay might be more closely related to fish productivity than salinity.

The estimation of fish biomass in the man grove ecosystem was done using the approach of nutrient release from mangrove litter. To the evaluation, the significant highest average fish production was in Jaring Halus $(3,063.05) \mathrm{kg}$ $\mathrm{ha}^{-1}$ year, and the significant lowest average fish production was in Percut (231.37) $\mathrm{kg}$ $\mathrm{ha}^{-1}$ year. The fisheries production found for Jaring Halus is much higher than the reported for Lubuk Kertang 1,248.76 $\mathrm{kg} \mathrm{ha}^{-1}$ year (Fitri et al., 2018). Litter production at the present study site was dominated by Rhizophora spp., followed by Avicennia spp as displayed in Table 6. The high production of Rhizophora litter is probably related to the high density of the species as compared to the other 
Table 6. Fish biomass estimation in five different sites.

\begin{tabular}{|c|c|c|c|c|c|c|c|c|c|c|}
\hline Site & Species & $\begin{array}{l}\text { Weight } \\
\text { (g) }\end{array}$ & $\begin{array}{l}\mathrm{N} \\
(\%)\end{array}$ & $\begin{array}{l}\mathrm{P} \\
(\%)\end{array}$ & $\begin{array}{l}\text { Nutrient } \\
\text { total } \\
\left(\mathrm{gm}^{-2}\right)\end{array}$ & $\begin{array}{c}\mathrm{PP} \\
\left(\mathrm{g} \mathrm{C} \mathrm{m}^{-2}\right)\end{array}$ & $\begin{array}{l}\mathrm{HF} \\
\left.5 \mathrm{~m}^{-2}\right)(\mathrm{g}\end{array}$ & $\begin{array}{r}\mathrm{CF} \\
\mathrm{m} 2)\end{array}$ & $\begin{array}{l}\text { Fish } \\
\text { Total } \\
\left(\mathrm{g} \mathrm{m}^{-2}\right)(\end{array}$ & $\begin{array}{c}\text { Fish } \\
\text { Production } \\
\mathrm{kg} \mathrm{ha}^{-1} \text { year) }\end{array}$ \\
\hline \multirow[t]{3}{*}{ Langsa } & Rhizophora spp. & 5.29 & 0.12 & 0.007 & 0.116 & 3.932 & 0.397 & 0.040 & 0.437 & \multirow[t]{3}{*}{$1,012.73 \pm 54.7 \mathrm{~b}$} \\
\hline & Avicennia spp. & 6.26 & 0.11 & 0.012 & 0.105 & 3.560 & 0.360 & 0.036 & 0.396 & \\
\hline & Sonneratia spp. & 0.00 & 0.00 & 0.000 & 0.000 & 0.000 & 0.000 & 0.000 & 0.000 & \\
\hline Jaring & Rhizophora spp. & 9.42 & 0.21 & 0.030 & 0.206 & 6.992 & 0.706 & 0.071 & 0.777 & \multirow[t]{3}{*}{$3,063.05 \pm 161.0 \mathrm{a}$} \\
\hline \multirow[t]{2}{*}{ Halus } & Avicennia spp. & 11.10 & 0.19 & 0.105 & 0.186 & 6.315 & 0.638 & 0.064 & 0.702 & \\
\hline & Sonneratia spp. & 11.73 & 0.28 & 0.009 & 0.275 & 9.353 & 0.945 & 0.094 & 1.039 & \\
\hline Pulau & Rhizophora spp. & 1.37 & 0.03 & 0.006 & 0.030 & 1.017 & 0.103 & 0.010 & 0.113 & \multirow[t]{3}{*}{$448.74 \pm 59.8 \mathrm{c}$} \\
\hline \multirow[t]{2}{*}{ Kampai } & Avicennia spp. & 1.32 & 0.02 & 0.000 & 0.022 & 0.753 & 0.076 & 0.008 & 0.084 & \\
\hline & Sonneratia spp. & 1.94 & 0.05 & 0.000 & 0.046 & 1.550 & 0.157 & 0.016 & 0.172 & \\
\hline Pulau & Rhizophora spp. & 2.41 & 0.05 & 0.000 & 0.053 & 1.791 & 0.181 & 0.018 & 0.199 & \multirow[t]{3}{*}{$465.89 \pm 38.4 \mathrm{c}$} \\
\hline \multicolumn{2}{|c|}{ SembilanAvicennia spp. } & 1.29 & 0.02 & 0.000 & 0.022 & 0.733 & 0.074 & 0.007 & 0.081 & \\
\hline & Sonneratia spp. & 1.16 & 0.03 & 0.000 & 0.027 & 0.922 & 0.093 & 0.009 & 0.102 & \\
\hline \multirow[t]{3}{*}{ Percut } & Rhizophora spp. & 0.75 & 0.02 & 0.000 & 0.016 & 0.558 & 0.056 & 0.006 & 0.062 & \multirow[t]{3}{*}{$231.37 \pm 40.7 \mathrm{~d}$} \\
\hline & Avicennia spp. & 2.03 & 0.03 & 0.000 & 0.034 & 1.153 & 0.116 & 0.012 & 0.128 & \\
\hline & Sonneratia spp. & 0.00 & 0.00 & 0.000 & 0.000 & 0.000 & 0.000 & 0.000 & 0.000 & \\
\hline
\end{tabular}

Data of Fish production are represented as mean $\pm \mathrm{SD}(\mathrm{n}=3)$. Means with the same superscript are not significantly different for each other $(\mathrm{P}<0.05)$ using Duncan's test. $\mathrm{N}=$ nitrogen, $\mathrm{P}=$ phosphorus, $\mathrm{PP}=$ primary productivity, $\mathrm{HF}$ $=$ herbirorous fish, $\mathrm{CF}=$ carnivorous fish .

species, as tree density is positively correlated with litter production (Chen et al., 2019).

Mangrove forest, through its litter production, significantly influenced fish production within the sites studied here. The increase of $\mathrm{N}$ at the early stage of decomposition is quite common due to immobilization (Nordhaus et al., 2017). Both $\mathrm{N}$ and $\mathrm{P}$ are actively involved in translocation, microbial growth, and metabolites, increasing levels during decomposition (Jiang et al., 2017). This result is positively linear correlated in most of the sites of our present study.

Within the mangrove ecosystem, there is at least one life cycle of various fish species and invertebrates in utilizing mangrove ecosystems as feeding places. The abundance of food is produced through litter production. The understanding of the carrying capacity of the mangrove ecosystem is the ability of the mangrove ecosystem as the area where to find food and or shelter in supporting the amount of biomass of fish through the transfer of energy that begins the production of organic materialderived from mangrove litter (detritus)
(Saifullah et al., 2016). The Leaves and detritus form a crucial part of marine food chains supporting fisheries.

Our results support previous positive relationships between estuarine mangrove forests and fishery resources (Aburto-Oropeza et al., 2008, Whitfield, 2017; Fitri et al., 2018) and add insight into the quantitative interaction between nutrient release and fish biomass. Mangrove forests in the Gulf of California have been reported to increase fishery yields up to $32 \%$ for small-scale fisheries (Aburto-Oropeza et al., 2008). On the other hand, high fishery productivity in natural mangroves is likely to be fully supported by adjacent estuaries (Raoult et al., 2018). It has been reported that the loss of one hectare of mangrove to a fish pond causes a loss of $480 \mathrm{~kg}$ of offshore fish and shrimp ha- $\mathrm{year}^{-1}$ (Ahmed et al., 2017). This study also implied the importance of mangrove conservation to protect the existing mangroves and restore degraded areas due to mangrove conversion. Further studies are needed to investigate the 
broader impact of mangrove conversion and mangrove loss on the fishing communities and production, particularly in Pulau Sembilan, Pulau Kampai, and Percut Sei Tuan.

\section{Conclusion}

Jaring Halus, as a natural mangrove forest, had the highest average fish production, and the lowest average fish production was found at the abandoned aquaculture ponds in Percut Sei Tuan, confirming that conservation and management affect mangrove productivity from primary productivity to secondary. The highest fish production followed the order of Jaring Halus $>$ Langsa $>$ (conserved mangroves), followed by Pulau Sembilan $>$ Pulau Kampai (palm oil plantations) and Sei Tuan Percut (aquaculture ponds), which is following their mangrove status and habitat zones. The present study provides information for the significant role of mangrove ecosystems for fisheries and calls for effective restoration from a perspective of food security.

\section{ACKNOWLEDGEMENTS}

A Research Grant fully supported this work from the Indonesian Science Fund and Indonesia Endowment Fund for Education (DIPI/LPDPUKRI Joint Call, Grant Number No. NE/ .(P014127.1

\section{References}

Abino, A.C.; Castillo, J.A.A. \& Lee, Y. J. (2014). Species diversity, biomass, and carbon stock assessments of a natural mangrove forest in Palawan, Philippines. Pakistan Journal of Botany, 46(6): 1955-1962.

Aburto-Oropeza, O.; Ezcurra, E.; Danemann, G.; Valdez, V.; Murray, J. et al. (2008). Mangroves in the Gulf of California increase fishery yields. Proceedings of the National Academy of Sciences, 105(30): 10456-10459.

Ahmed, N.; Cheung, W. W.; Thompson, S. \& Glaser, M. (2017). Solutions to blue carbon emissions: Shrimp cultivation, mangrove deforestation and climate change in coastal Bangladesh. Marine Policy, 82: 68-75.

Al-Bader, D.A.; Shuail, D.A.; Al-Hasan, R. \& Suleman P. (2014). Intertidal seagrass Halodule uninervis: Factors controlling its density, biomass, and shoot length. Kuwait Journal of Science, 41(1): 171-192.

Al-Enezi, E.; Al-Ghadban, A.N.; Al-Refai, I.; Pieretti, N. \& Frontalini F. (2019). Living benthic foraminifera around the unique Umm al Maradim Island (Kuwait). Kuwait Journal of Science, 46(2):59-66

Ananda, K.; Sridhar, K.R.; Raviraja, N.S.; Brälocher, F. (2007). Breakdown of fresh and dried Rhizophora mucronata leaves in a mangrove Southwest India. Wetlands Ecology and Management 16: 1-9

Aznan, A.S.; Lee, K. L.; Low, C. F.; Iberahim, N.A.; Ibrahim, W.N.W.et al.(2018). Protective effect of apple mangrove Sonneratia caseolaris extract in Edwardsiella tarda-infected African catfish, Clarias gariepinus. Fish \& Shellfish Immunology, 78: 338-345.

Barbier, E.B.; Hacker, S.D.; Kennedy, C. (2011). The value of estuarine and coastal ecosystem services. Ecological Monographs, 81: $169-193$

Basyuni, M.; Putri, L.A.P.; Nainggolan, B. \& Sihaloho, P.E. (2014). Growth and biomass in response to salinity and subsequent fresh water in mangrove seedlings Avicennia marina and Rhizophora stylosa. Jurnal Manajemen Hutan Tropika, 20(1): 17-25.

Basyuni, M.; Wasilah, M.; Hasibuan, P.A.Z.; Sulistiyono, N.; Sumardi, S. et al. (2019). Salinity and subsequent freshwater influences on the growth, biomass, and polyisoprenoids distribution of Rhizophora apiculata seedlings. Biodiversitas, 20(1): 388395. 
Beveridge, M.C.M. (1984). Cage and Pen Fish Farming: Carrying Capacity Models and Environment Impact. FAO Fisheries Technical Paper 225 FAO-UN Rome.

Borkar, M.U.; Athalye, R.P. \& Goldin, Q. (2011). Salinity induced changes in the leaf anatomy of the mangrove Avicennia marina along the anthropogenically stressed tropical creek. Journal of Coastal Development, 14(3): 191-201.

Chambers, L.G.; Osborne, T.Z. \& Reddy, K.R. (2013). Effect of salinity-altering pulsing events on soil organic carbon loss along an intertidal wetland gradient: a laboratory experiment. Biogeochemistry, 115(1-3): 363383.

Chen, J.; Chen, G.; Gu, Y.; Zhu, H. \& Ye, Y. (2019). Fate of leaf litter in restored Kandelia obovata (SL) mangrove forests with different ages in Jiulong River Estuary, China. Restoration Ecology, 28(2): 369-377.

Contreras, L.M.; Fierro-Cabo, A. \& CintraBuenrostro, C.E., (2017). Early drivers of Black Mangrove (Avicennia germinans) leaf litter decomposition in the water column. Hydrobiologia, 803: 147-157.

Crawshaw, J.; O'Meara, T.; Savage, C.; Thomson, B.; Baltar, F. et al. (2019). Source of organic detritus and bivalve biomass influences nitrogen cycling and extracellular enzyme activity in estuary sediments. Biogeochemistry, 145(3): 315-335.

Dangremond, E. M.; Feller, I. C. \& Sousa, W. P. (2015). Environmental tolerances of rare and common mangroves along light and salinity gradients. Oecologia, 179(4): 1187-1198.

Dasgupta S. \& Long P.M. (2005). Performance guarantees for hierarchical clustering. Journal of Computer and System Sciences, 70: 555-567.
Davis, S.E.; Corronado-Molina, C.; Childers, DL \& Day, J.W. Jr. (2003). Temporally dependent $\mathrm{C}, \mathrm{N}$, and $\mathrm{P}$ dynamics associated with the decay of Rhizophora mangle L. leaf litter in oligotrophic mangrove wetlands of the Southern Everglades. Aquatic Botany 75(3):199-215.

Ellison, A.M. (2000). Mangrove restoration: do we know enough? Restoration Ecology 8:219-229.

Fitri, A.; Basyuni, M.; Wati, R.; Sulistiyono, N.; Slamet, B. et al. (2018). Management of mangrove ecosystems for increasing fisheries production in Lubuk Kertang Village, North Sumatra, Indonesia. AACL Bioflux, 11(4): 1252-1264.

Friedland, K.D.; Stock, C.; Drinkwater, K.F.; Link, J.S. \& Leaf, R.T. (2012). Pathways between primary production and fisheries yields of large marine ecosystems. PloS one, 7(1): e28945.

Gil-Weir, K.; Weir, E.; Casler, C.L. \& Aniyar, S. (2011). Ecological functions and economic value of the Neotropic Cormorant (Phalacrocorax brasilianus) in Los Olivitos Estuary, Venezuela. Environment and Development Economics, 16(5): $553-572$.

Hossain, M.D. \& Nuruddin, A.A. (2016). Soil and mangrove: a review. Journal of Environmental Science and Technology, 9(2): 198-207.

Hutchison, J.; Manica, A.; Swetnam, R.; Balmford, A. \& Spalding, M. (2014a). Predicting global patterns in mangrove forest biomass. Conservation Letters, 7(3): 233-240.

Hutchison,J.; Spalding, M.\&Zu Ermgassen, P. (2014b). The role of mangroves in fisheries enhancement. The Nature Conservancy and Wetlands International, 54. 
Jiang, S.; Weng, B.; Liu, T.; Su, Y.; Liu, J. et al. (2017). Response of phenolic metabolism to cadmium and phenanthrene and its influence on pollutant translocations in the mangrove plant Aegiceras corniculatum (L.) Blanco (Ac). Ecotoxicology and Environmental Safety, 141: 290-297.

Kodikara, K.A. S.; Jayatissa, L. P.; Huxham, M.; Dahdouh-Guebas, F. \& Koedam, N. (2018). The effects of salinity on the growth and survival of mangrove seedlings change with age. Acta Botanica Brasilica, 32(1): 3746.

Li, T. \& Ye, Y. (2014). Dynamics of decomposition and nutrient release of leaf litter in Kandelia obovata mangrove forests with different ages in Jiulongjiang Estuary, China. Ecological Engineering, 73: 454-460.

Liu, X.; Xiong, Y., \& Liao, B. (2017). Relative contributions of leaf litter and fine roots to soil organic matter accumulation in mangrove forests. Plant and Soil, 421(1-2): 493-503.

Marquez, A.M.; Fierro-Cabo, A. \& CintraBuenrostro, C.E. (2017). Can ecosystem functional recovery be traced to decomposition and nitrogen dynamics in estuaries of the Lowe Laguna Madre, Texas? Restoration Ecology, 25: 618-628.

Méndez-Alonzo, R.; López-Portillo, J.; Moctezuma, C.; Bartlett, M. K. \& Sack, L. (2016). Osmotic and hydraulic adjustment of mangrove saplings to extreme salinity. Tree Physiology, 36(12): 1562-1572.

Middleton, B.A. \& McKee K.L. (2001). Degradation of mangrove tissues and implications for peat formation in Belizean island forests. Journal of Ecology 89: 818-828.

Nagelkerken, I.S.J.M.; Blaber, S.J.M.; Bouillon, S.; Green, P.; Haywood, M. et al. (2008). The habitat function of mangroves for terrestrial and marine fauna: a review. Aquatic Botany, 89(2): 155-185.
Nordhaus, I.; Salewski, T. \& Jennerjahn, T.C. (2017). Interspecific variations in mangrove leaf litter decomposition are related to labile nitrogenous compounds. Estuarine, Coastal and Shelf Science, 192: 137-148.

Phuphumirat, W.; Zetter, R.; Hofmann,C.C. \& Ferguson, D. K. (2016). Pollen distribution and deposition in mangrove sediments of the Ranong Biosphere Reserve, Thailand. Review of Palaeobotany and Palynology, 233: 22-43.

Raoult, V.; Gaston, T.F. \& Taylor, M.D. (2018). Habitat-fishery linkages in two major south-eastern Australian estuaries show that the C4 saltmarsh plant Sporobolus virginicus is a significant contributor to fisheries productivity. Hydrobiologia, 811(1): 221-238.

Saifullah, A.S.M.; Kamal, A.H.M.; Idris, M.H.; Rajaee, A.H. \& Bhuiyan, M.K.A. (2016). Phytoplankton in tropical mangrove estuaries: role and interdependency. Forest Science and Technology, 12(2), 104-113.

Sheaves, M.; Baker, R.; Abrantes, K.G. \& Connolly, R.M. (2017). Fish biomass in tropical estuaries: substantial variation in food web structure, sources of nutrition, and ecosystem-supporting processes. Estuaries and Coasts, 40(2): 580-593.

Strydom, N.A. \& Kisten, Y. (2020). Review of fish life-history strategies associated with warm-temperate South African estuaries and a call for effective integrated management. African Journal of Aquatic Science, 45: 217227.

Thatoi, H.; Behera, B.C.; Mishra, R.R. \& Dutta, S.K. (2013). Biodiversity and biotechnological potential of microorganisms from mangroveecosystems: a review. Annals of Microbiology, 63(1): 1-19.

Valiela, I.; Bowen, J.L. \& York J.K. (2001). Mangrove forests: one of the world's threatened tropical environments. BioScience, 51: 807815. 
Vovides, A.G.; Bashan Y.; López-Portillo J.A. \& Guevara R. (2011a). Nitrogen fixation in preserved, reforested, naturally regenerated, and impaired mangroves as an indicator of functional restoration in mangroves in an arid region of Mexico. Restoration Ecology, 19: 236-244.

Vovides, A.G.; López-Portillo J.A.; Bashan Y. (2011b). N2-fixation along a gradient of long-term disturbance in tropical mangroves bordering the Gulf of Mexico. Biology and Productivity of Soils, 47: 567-576.

Whitfield, A.K. (2017). The role of seagrass meadows, mangrove forests, salt marshes, and reed beds as nursery areas and food sources for fishes in estuaries. Reviews in Fish Biology and Fisheries, 27(1): 75-110.

Zaldívar-Jiménez, M.A.; Herrera-Silveira, J.A.; Teutli-Hernández, C. (2010). Conceptual framework for mangrove restoration in the Yucatán Peninsula. Ecological Restoration, 28: 333-342.

Zhila, H.; Mahmood, H. \& Rozainah, M.Z. (2014). Biodiversity and biomass of a natural and degraded mangrove forest of Peninsular Malaysia. Environmental Earth Sciences, 71(11): 4629-4635.

$\begin{array}{lr}\text { Submitted: } & 12 / 02 / 2020 \\ \text { Revised: } & 07 / 05 / 2020 \\ \text { Accepted: } & 09 / 05 / 2020 \\ \text { DOI: } & 10.48129 / \text { kjs.v48i3.9160 }\end{array}$

